\title{
UNGKAPAN METAFORIS TEKS TERJEMAHAN AL-QUR'AN BAHASA SUNDA SURAT AL-BAQARAH: ANALISIS SEMANTIK KOGNITIF
}

\author{
Shifa Nur Zakiyah ${ }^{1}$ dan Tajudin Nur ${ }^{2}$ \\ Magister Ilmu Linguistik, Fakultas Ilmu Budaya, Universitas Padjadjaran ${ }^{1,2}$ \\ Surel: shifa16001@ mail.unpad.ac.id ${ }^{1}$ \\ tajudin.nur@unpad.ac.id ${ }^{2}$
}

\begin{abstract}
Abstrak
Penelitian ini bertujuan untuk mendeskripsikan ungkapan metafora yang ada dalam Al-Qur'an terjemah bahasa Sunda dengan pembahasan dikhususkan pada jenis-jenis metafora dan skema citra yang ada dalam surat Al-Baqarah. Penelitian ini dilakukan dengan menggunakan metode deskriptif serta proses analisis menggunakan kajian semantik kognitif. Teori yang digunakan untuk menganalisis data adalah teori semantik kognitif mengenai jenis-jenis metafora menurut Lakoff dan Johnson (2013) serta teori mengenai skema citra menurut Cruse dan Croft (2004). Hasil dari penelitian ini ditemukan 15 data ungkapan metafora dalam terjemah Al-Qur'an berbahasa Sunda surat Al-Baqarah yang terbagi menjadi tiga jenis metafora konseptual, yaitu (1) metafora struktural, (2) metafora orientasional, dan (3) metafora ontologi. Sedangkan skema citra yang ditemukan dalam penelitian ini sebanyak 5 macam data diantaranya, 1 data skema citra identitas (identity), 1 data skema citra kekuatan (force), 1 data skema citra wadah (container), 3 data skema citra eksistensi (excistence) dan 3 data skema citra kesatuan (unity).
\end{abstract}

Kata Kunci: metafora, semantik kognitif, Al-Qur’an, Al-Baqarah, Sunda

\section{Abstract}

This study aims to describe the metaphorical expressions in the Sundanese translation of the Qur'an with a special discussion on the types of metaphors and image schemes that exist in the surah Al-BaqarahrnThis research was conducted using descriptive methods and the analysis process used cognitive semantic studies. The theory used to analyze the data is the cognitive semantic theory regarding the types of metaphors according to Lakoff and Johnson (2013) and the theory of image schemes according to Cruse and Croft (2004). The results of this study found 15 data of metaphorical expressions in the Sundanese translation of the Al-Baqarah letter which are divided into three types of conceptual metaphors, namely (1) structural metaphors, (2) orientational metaphors, and (3) ontological metaphors. While the image schemes found in this study consist of 5 kinds of data including, 1 data of identity image schemes, 1 data of force image schemes, 1 data of container image schemes, 3 data of excistence image schemes, and 3 data of unity image schemes.

Keywords: metaphor, semantic cognitive, Qur'an, Al-Baqarah, Sundanese 


\section{PENDAHULUAN}

Kegiatan berbahasa merupakan sebuah kegiatan yang tidak dapat dilepaskan dengan manusia dalam kehidupan sehari-hari, baik kegiatan bahasa secara verba ataupun nonverbal. Bahasa digunakan oleh manusia untuk berkomunikasi antara satu dengan lainnya. Penggunaan bahasa untuk berkomunikasi berguna untuk mengungkapkan sebuah perasaan, ide, maksud dan gagasan dari sebuah tuturan yang dituturkan manusia. Chaer (2007: 44) menjelaskan bahwa bahasa merupakan sebuah sistem lambang yang memiliki wujud bunyi atau sebuah bunyi ujar. Lambang tersebut merupakan sebuah pengertian, sebuah ide, sebuah konsep, atau sebuah pikiran yang akan disampaikan dalam wujud bunyi tersebut. Oleh karena itu, sebuah lambang mengacu pada sebuah ide, konsep, dan pikiran maka dapat dikatakan bahwa sebuah bahasa memiliki makna. Dalam linguistik terdapat cabang ilmu yang mengkaji sebuah makna bahasa yang biasa disebut dengan semantik.

Manusia memiliki pikiran yang berfungsi mengatur sebuah pengetahuan atau informasi yang didapatnya dari pengalaman hidup sendiri atau pengalaman hidup orang Jur lain. Pengalaman hidup setiap orang berbedabeda, pikiran atau kognisi masingmasing orang juga berbeda. Pikiran tersebut termasuk dalam pengalaman secara langsung maupun tidak langsung. Proses pengolahan pikiran atau proses kognitif tersebut dapat menghasilkan sebuah metafora (Irwansyah, Wagiati, dan Darmayanti, 2019: 225).

Menurut Knowles dan Moon (2006: 3) metafora adalah bentuk yang digunakan dalam bahasa yang berfungsi untuk menyebutkan sesuatu yang diterapkan kepada yang lain berdasarkan hubungan kemiripan. Pada metafora terdapat sebuah proses pentransferan dari satu konsep ke konsep lainnya. Dengan adanya dasar transfer tersebut dapat dijadikan sebuah prinsip dasar untuk menentukan apakah sebuah kata masuk dalam metafora atau tidak. Saeed (2009: 345) juga berpendapat bahwa metafora merupakan hiasan dalam sebuah bahasa dan bukan berbentuk bahasa biasa. Metafora sebagai sebuah alat retoris yang dapat digunakan pada saat-saat tertentu untuk menghasilkan sesuatu efek tertentu. Secara tidak langsung metafora diartikan sebagai sebuah bentuk bahasa yang tidak normal dan menuntut adanya interpretasi dari pendengar atau pembacanya.

Dalam ilmu linguistik juga terdapat ilmu bahasa yang mempelajari bahasa dengan kognisi biasa disebut dengan linguistik kognitif. Arimi (2015: 5) dalam (Dessiliona dan Nur, 2018: 178) menerangkan mengenai semantik kognitif yang merupakan sebuah pendekatan eksperimental yang berdasarkan pada bagaimana bahasa digunakan dan dialami senyatanyatanya. Evans dan Green (2006) serta Cuyckens dan Geeraets (2012) dalam (Aulia dan Nur, 2020: 227) menjelaskan bahwa linguistik kognitif merupakan sebuaheroistudi yang mempelajari mengenai bagaimana seseorang berpikir terhadap sesuatu yang diujarkan melalui bahasa. Linguistik kognitif merupakan hubungan antara bahasa dan fungsi kognisi seseorang.

Ilmu untuk mempelajari konsep atau makna yang berhubungan dengan kognisi disebut semantik kognitif. Dalam semantik kognitif membahas mengenai bentuk-bentuk metafora. MacCormac (1985: 2) dalam (Karnedi, 
2011: 19) menjelaskan bahwa metafora ialah proses kognitif yang dapat menghasilkan pemahaman baru dengan cara mengubah bahasa. Pemahaman baru tersebut muncul berdasarkan pada sejauh mana pembaca atau mitra tutur memahami maksud dari konstruksi frasa, klausa, atau kalimat yang diciptakan. Bentuk metafora umumnya banyak digunakan dalam kegiatan berbahasa sehari-hari, secara tidak sadar maupun sadar dalam setiap ujaran tidak menutup kemungkinan terdapat sebuah kata metafora di dalamnya.

Seperti pada penelitian yang dilakukan oleh Riani (2015: 22-32) yang membahas tentang ungkapan metafora kata banjir, gempa, dan letusan gunung di media massa baik televisi maupun internet. Hasil dari penelitian tersebut menunjukkan bahwa penggunaan metafora kata-kata seperti banjir, gempa dan letusan gunung banyak digunakan. Salah satu contohnya, banjir melumpuhkan jalan ibukota yang mengibaratkan banjir sebagai makhluk hidup yang dapat menyebabkan kerugian yaitu melumpuhkan. Lalu, dilihat dari sudut pandang penggunaan metafora di masyarakat yang menunjukkan penggunaan metafora seperti kata banjir, gempa dan gunung meletus yang merupakan bencana alam diidentikkan menimbulkan kerugian dalam masyarakat.

Ungkapan metafora juga terdapat pada lirik-lirik lagu yang biasanya digunakan untuk menciptakan sebuah permainan kata yang dapat menjadi daya tarik terhadap lirik tersebut. Fokkaya (2018: 93-99) menjelaskan pada penelitiannya yang mengungkap tentang gaya bahasa pada lirik lagu Iwan Fals yang di dalamnya terkandung makna kritik sosial. Hal tersebut merupakan sebuah cara yang dilakukan untuk menyampaikan kritik terhadap sebuah ketidakadilan yang dilakukan oleh pemerintah kepada rakyat. hasil penelitian tersebut menunjukkan bahwa kritik sosial yang ada dalam lirik lagu Iwan Fals mengenai masalah korupsi, penegakan hukum, kemiskinan, pengangguran dan kolusi. Seperti pada masakah korupsi, digunakan kata tikustikus yang berkonotasi kepada para koruptor dan kata kucing untuk para penegak hukum.

Berdasarkan penelitian-penelitian yang sudah dilakukan sebelumnya, terlihat bahwa ungkapan metafora sudah banyak dan sering digunakan dalam kehidupan sehari-hari. Dalam Al-Qur'an juga terdapat banyak ungkapanungkapan yang mengandung metafora. Al-Qur'an ditulis dengan menggunakan bahasa Arab dan juga sudah banyak diterjemahkan dalam berbagai bahasa salah satunya bahasa Sunda. Walaupun sudah diterjemahkan dalam berbagai bahasa, tetapi ungkapan-ungkapan metafora tersebut tetap muncul. Oleh karena itu, penelitian ini bertujuan untuk mendeskripsikan tentang jenis-jenis metafora dan skema citra melalui ungkapan metafora dalam Al-Qur'an dengan terjemah bahasa Sunda khususnya surat Al-Baqarah.

Metafora konseptual diperkenalkan pertama kali oleh Lakoff dan Johnson (1980) dalam (Meganova Lyra, 2018: 58) menjelaskan bahwa metafora secara tidak sengaja diciptakan dan melebur dalam bahasa sehari-hari. Metafora tersebut hadir dari sebuah konstruksi mental serta konseptualisasi dari pengalaman hidup setiap orang.

Lakoff dan Johnson (2003: 10-32) menjelaskan metafora merupakan sebuah hasil dari konstruksi mental yang berdasarkan pada prinsip analogi mengenai konseptualisasi suatu unsur 
kepada unsur lainnya. Dengan kata lain, metafora merupakan sebuah mekanisme kognitif yang terdapat pada satu ranah sumber (ranah pengalaman) yang dipetakan kepada ranah sasaran (ranah pengalaman lainnya) sehingga kedua ranah tersebut dapat dipahami dari ranah pertama. Metafora konseptual memahami mengenai transfer dari ranah sumber (source domain) ke ranah sasaran (targer domain). Pada proses pentransferan tersebut ranah sumber (source domain) digunakan untuk memahami bagaimana konsep abstrak dalam sebuah ranah sasaran (targer domain). Bentuk dari ranah sumber biasanya berupa hal-hal yang ada pada kehidupan sehari-hari yang bersifat konkret. Seperti pada kalimat, Dia sudah keluar dari masalahnya yang terlihat adanya proses pentransferan antara ranah sumber ke ranah sasaran. Pada kalimat tersebut kata masalah yang merupakan sesuatu yang abstrak dianalogikan menjadi sesuatu yang konkret dengan seakan-akan berada dalam dimensi ruang yang dikonkretkan dengan kata keluar.

Lakoff dan Johnson (2003: 10-32) yang diperjelas oleh Knowles dan Moon (2006: 33) serta Kovesces (2010: 17-28) menjelaskan bahwa terdapat tiga komponen dalam metafora konseptual,

yaitu:
1. Ranah sumber (source domain)
Pendidikan B Ranah sumber (source domain) merupakan ranah yang memiliki sifat konkret. Dalam semantik klasik, ranah sumber disebut sebagai wahana (vehicle). Ranah sumber (source domain) terdiri dari sebuah kumpulan entitas, atribut, dan juga proses yang terhubung secara sistematis dan harfiah serta tersimpan dalam pikiran. Hal tersebut diungkapkan dengan cara mengungkapkan seperangkat kata atau ungkapan yang dianggap terkumpul dalam sebuah kelompok yang serupa dan sering disebut oleh linguis sebagai lexical sets (kelompok leksikal).

2. Ranah sasaran (target domain)

Ranah sasaran (target domain) merupakan ranah yang cenderung bersifat abstrak serta lebih mengikuti struktur yang terdapat pada ranah sumber melalui proses pemetaan (mapping). Proses pemetaan (mapping) ini yang disebut sebagai metafora konseptual. Dalam semantik klasik, ranah sasaran (target domain) disebut sebagai tenor. Pada ranah sasaran (target domain), entitas, atribut, serta proses diyakini saling berhubungan satu dengan lainnya seperti pola pemetaan yang timbul dari hubungan entitas, atribut serta prosess yang terjadi dalam ranah sumber (source domain).

3. Pemetaan (mapping atau correspondence)

Dalam semantik klasik pemetaan (mapping) disebut sebagai dasar metafora. Pada pemetaan (mapping) dihasilkan sebuah titik persesuaian (similarities) yang terjadi antara ranah sumber (source domain) dengan ranah sasaran (target domain) dengan cara mengangkat (highlighting) hal-hal yang dianggap penting yang sama dan menyembunyikan (hiding) hal-hal yang tidak dianggap penting atau tidak perlu diangkat.

Metafora konseptual menurut Lakoff dan Johnson (2003: 10-32) dalam (Haula, 2020: 17-18) terbagi dalam tiga jenis metafora, yaitu metafora struktural, metafora orientasional dan metafora ontologi. 
1. Metafora struktural merupakan sebuah konsep metafora yang dibentuk dengan menggunakan konsep yang lain. Metafora struktural ini berdasarkan pada dua ranah, ranah sumber dan ranah sasaran. Metafora struktural berdasarkan pada hubungan sistematis dalam pengalaman di kehidupan seharihari.

2. Metafora orientasional merupakan sebuah konsep metafora yang berhubungan dengan orientasi ruang, seperti naik-turun, dalam-luar, depan-belakang, pusat-keliling, dan lain-lain. Orientasi ruang tersebut muncul dari sebuah kenyataan bahwa kita manusia memiliki tubuh dan tubuh berfungsi dalam lingkungan fisik. Metafora orientasional lebih mendasarkan pada pengalaman fisik manusia dalam mengatur arah pada kehidupan sehari-hari.

3. Metafora ontologi merupakan sebuah konsep metafora yang mengonseptualisasikan pikiran, pengalaman, dan proses dari hal abstrak ke sesuatu yang memiliki sifat fisik. Secara tidak langsung, metafora ontologi menganggap bahwa nomina abstrak sebagai sebuah nomina konkret.

Selain mengenai jenis-jenis metafora, semantik kognitif Jurjuga membahas mengenai skema citra yang terbentuk dari sebuah metafora. Saeed (2009: 353) menjelaskan bahwa skema citra termasuk bentuk penting dari bagian konseptual semantik kognitif. Skema citra merupakan sebuah struktur makna yang terbentuk dari pengalaman yang dihasilkan dari bagaimana tubuh berinteraksi dengan dunia. Pengalaman tersebut berfungsi sebagai alat untuk memahami secara abstrak serta memahami sebuah kebenalaran.
Kemudian, dipertegas oleh Danesi (2011: 95) yang berpendapat bahwa skema citra adalah kerangka mental tak sadar yang berasal dari bentuk, tindakan, dimensi, dan seterusnya yang terus berulang dan berasal dari persepsi serta perasaan. Sebagian besar dari bentuk skema citra bersifat tidak sadar, akan tetapi dapat dibangkitkan dengan mudah. Ketidaksadaran tersebut membuat pembaca atau lawan bicara secara tidak sadar memvisualisasikan skema citra dengan orientasi-orientasi yang ada. Seperti perasaan ketika kita ketika berada 'di atas', skema citra yang muncul adalah secara tidak sadar kita akan memvisualisasikan dengan orientasi ruang yang berhubungan dengan dimensi atas serta dimensi bawahnya.

Skema citra menurut Croft dan Cruse (2004: 45) dalam (Devita dan Nur, 2020: 88) terbagi menjadi tujuh bagian yang disusun dalam tabel berikut ini.

\section{Tabel 1}

\section{Skema Citra Cruse dan Croft}

\begin{tabular}{|c|c|}
\hline Skema Citra & Jenis \\
\hline Space & $\begin{array}{l}\text { Up-Down, Front- } \\
\text { Back, Left-Right, } \\
\text { Near-Far, Center- } \\
\text { Periphery, Contact. }\end{array}$ \\
\hline Scale & Path. \\
\hline Container & $\begin{array}{l}\text { Containment, In- } \\
\text { Out, Surface, Full- } \\
\text { Empty, Content. }\end{array}$ \\
\hline Force & $\begin{array}{l}\text { Balance, } \\
\text { Counterforce, } \\
\text { Compulsion, } \\
\text { Restraint, } \\
\text { Enablement, } \\
\text { Blockage, Diversion, } \\
\text { Attaction. }\end{array}$ \\
\hline
\end{tabular}




\begin{tabular}{|l|l|}
\hline Unity/ & Merging, Collection, \\
Multiplicity & $\begin{array}{l}\text { Splitting, Iteration, } \\
\text { Part-Whole, Mass- } \\
\text { Count, Link. }\end{array}$ \\
\hline Identity & $\begin{array}{l}\text { Matching, } \\
\text { Superimposition. }\end{array}$ \\
\hline Excistence & $\begin{array}{l}\text { Removal, Bounded } \\
\text { Space, Cycle, } \\
\text { Object, Process. }\end{array}$ \\
\hline
\end{tabular}

\section{METODE}

Metode merupakan cara yang digunakan secara teratur dan terpikirkan secara baik-baik untuk mencapai sebuah maksud. Djajasudarma (2010: 4) mengemukakan bahwa metodologi penelitian bahasa memiliki hubungan erat dengan tujuan dari penelitian bahasa. Pada penelitian ini secara umum menggunakan metode penulisan analisis deskriptif. Metode deskriptif bertujuan untuk mendeskripsikan sehingga dapat terlihat gambaran mengenai data secara sistematis, faktual dan akurat. Proses analisis dalam penelitian ini menggunakan metode kualitatif dengan kajian semantik kognitif.

Langkah-langkah yang dilakukan dalam penelitian ini adalah:

1. melakukan studi pustaka untuk mendapatkan data serta teori yang berhubungan dengan data yang akan diteliti;

2. pengumpulan data, dengan urara memilah ungkapan metafora yang termasuk dalam permasalahan yang akan dianalisis;

3. pengklasifikasian data;

4. penganalisisan data sesuai dengan teori yang ada; dan

5. penyimpulan hasil penelitian serta jawaban dari masalah yang diteliti.

Metode analisis yang digunakan untuk menganalisis data dalam penelitian ini ialah semantik kognitif dari Lakoff dan Johnson (2003) yang digunakan sebagai alat penentu sebuah frasa termasuk dalam ungkapan metafora atau bukan berdasarkan teori karakteristik serta jenis metafora. Terakhir, untuk menentukan jenis skema citra yang ada dalam ungkapan metafora yang akan dianalisis menggunakan teori dari Croft dan Cruse (2004).

\section{HASIL DAN PEMBAHASAN}

Dalam penelitian ini ditemukan 15 data yang termasuk ungkapan metafora yang ada dalam Al-Qur'an terjemah bahasa Sunda. Pembahasan berikut ini akan membahas data mengenai ungkapan metafora yang ada dalam AlQur'an terjemah bahasa Sunda berdasarkan jenis metafora serta skema citra yang ditemukan dengan masingmasing akan diwakilkan sebanyak 3 data dan setiap jenis metafora.

\section{Metafora Struktural}

1. Pamajikan maranéh téh sawah maranéh, ku kituna geura datangan nu jadi sawah maranéh téh sakarep maranéh, (Al-Baqarah : 223)

"Istri kalian adalah sawah kalian, maka dari itu lekas datangi yang menjadi sawah kalian itu semau kalian."

Istri-istrimu adalah ladang bagimu, maka datangilah ladangmu itu kapan saja dengan cara yang kamu sukai.

Sumber: Sawah 'sawah'

Sasaran : Pamajikan 'istri'

Skema Citra : Identity jenis matching

Analisis : Pada data (1) termasuk pada metafora struktural karena memiliki ciri adanya kata sawah. Ranah sumber yang terdapat pada data (1) adalah sawah dan yang menjadi ranah sasaran adalah pamajikan 'istri'. Kata sawah memiliki makna leksikal yaitu 
sebuah lahan yang digarap dan diairi untuk dijadikan tempat menanam padi. Sedangkan kata pamajikan 'istri' memiliki makna leksikal perempuan yang sudah menikah atau sebutan untuk istri. Persamaan konsep antara sawah dengan seorang istri sebagai sesuatu yang dapat ditanami. Sawah sebagai tempat yang dapat ditanami benih padi, sedangkan seorang istri sebagai tempat mengandung anak. Persamaan konsep di antara ranah sumber dengan ranah sasaran membentuk sebuah skema citra identitas (identity) yang memiliki ciri kecocokan sebuah konsep (matching).

2. Allah geus nutup haté katut pandéngé maranéhna, poma kitu deui panénjo geus ditutup, jeung pikeun maranéhna siksaan nu beurat. (AlBaqarah: 7)

"Allah sudah menutup hati serta pendengaran mereka, awas begitu juga penglihatan sudah ditutup, dan bagi mereka siksaan yang berat."

Allah telah mengunci mati hati dan pendengaran mereka, dan penglihatan mereka ditutup. Dan bagi mereka siksaan yang amat berat.

Sumber : Nutup hate 'menutup hati' Sasaran : Petunjuk 'petunjuk'urnal Ilmiah Skema Citra : Force jenis blockage Analisis : Pada data (2) termasuk dalam metafora struktural karena memiliki ciri adanya kata nutup haté 'menutup hati'. Ranah sumber yang terdapat pada data (2) adalah nutup hate 'menutup hati' dan yang menjadi ranah sasaran adalah petunjuk. Kata nutup hate memiliki makna leksikal menutup hati, sedangkan petunjuk memiliki makna sesuatu yang digunakan untuk menunjukkan, memberitahu, dan lainya. Persamaan antara ranah sumber dengan ranah sasaran dijelaskan dalam tafsir, Qatadah mengatakan bahwa syaitan telah menguasai mereka karena mereka telah menaatinya. Maka Allah mengunci mati hati, pendengaran serta pandangan mereka sehingga mereka tidak dapat melihat petunjuk, tidak dapat mendengar, tidak dapat memahami serta tidak dapat berpikir. Kedua kata tersebut mencitrakan sebuah konsep kekuatan (force) berupa penghalang (blockage) karena ungkapan metafora nutup hate 'menutup hati' menunjukkan adanya sebuah penghalang untuk masuknya sebuah petunjuk karena sudah terhalang oleh kekufuran.

3. Kagungan Allah saniskara anu aya di langit jeung saniskara anu aya di bumi. Jeung upaman ditembrakkeun saeusining haté maranéh, boh upama ku maranéh disumputkeun ogé, kabéhanana bakal dihisab ku Allah. (Al-Baqarah: 284)

"Keagungan Allah segala macam yang ada di langit dan segala macam yang ada di bumi. Dan seumpamanya ditunjukkan semua isi hati kalian, baik seumpamanya disembunyikan juga, semuanya akan dihisab oleh Allah", sas

Kepunyaan Allah-lah segala apa yang ada di langit dan di bumi. Dan jika kamu melahirkan apa yang ada di dalam hatimu atau kamu menyembunyikannya, niscaya Allah akan membuat perhitungan dengan kamu tentang perbuatanmu itu.

Sumber : Saeusining haté 'semua isi hati'

Sasaran : Niat dan rencana manusia 'Niat dan rencana manusia' 
Skema Citra : Container jenis content

Analisis : Pada data (3) termasuk dalam metafora struktural karena miliki ciri adanya kata saeusining haté. Ranah sumber yang terdapat pada data (3) adalah saeusining haté 'semua isi hati' yang memiliki makna leksikal semua isi hati, sedangkan yang menjadi ranah sasaran adalah niat yang memiliki makna leksikal maksud atau tujuan suatu perbuatan. Persamaan konsep antara ranah sumber dengan ranah sasaran dalam metafora di atas adalah semua isi hati yang dimaksudkan merupakan apa-apa saja yang telah dilakukan oleh manusia baik yang disembunyikan juga akan terlihat oleh Allah karena menurut hadits dari Ibnu Abbas menerangkan bahwa sesungguhnya Allah mencatat seluruh perbuatan baik dan perbuatan buruk. Dari persamaan konsep tersebut membentuk skema citra wadah (container) yang memiliki ciri kandungan atau isi (content) karena hati menunjukkan sebuah tempat yang berisikan segala niat atau rencana manusia.

\section{Metafora Orientasional}

4. Tuluy sétan ngagoda (ka Adam jeung Hawa) nepi ka duanana tisoledat tina to'at. (Al-Baqarah : 36)

"Lalu setan menggoda (ke Adam dan Hawa) sampai keduanya tergelincir dari taat."

Lalu, setan memperdaya keduanya dari surga sehingga keduanya dikeluarkan dari (segala kenikmatan).

Sumber : Tisoledat 'tergelincir' Sasaran : To'at 'ketaatan'
Skema Citra : Excistence jenis process

Analisis : Pada data (4) termasuk dalam jenis metafora orientasional, yang memiliki ciri yaitu adanya kata tisoledat 'tergelincir'. Ranah sumber yang terdapat pada data (4) adalah tisoledat 'tergelincir' dan yang menjadi ranah sasaran adalah to'at 'ketaatan'. Kata tisoledat terdiri dari $t i+$ soledat yang memiliki arti terjatuh karena menginjak sesuatu yang licin ketika berjalan dan kata to'at memiliki arti ketaatan. Dalam kalimat metafora ini kata tisoledat 'tergelincir' memiliki makna konseptual beringkar kepada Allah, karena sebelumnya Allah sudah melarang Adam dan Hawa memakan buah dari suatu pohon. Akan tetapi karena Adam dan Hawa menuruti godaan syaitan sehingga keduanya ingkar kepada Allah dan keduanya dikeluarkan dari keadaan semula. Konsep yang ditransfer antara ranah sumber dengan ranah sasaran adalah sesuatu hal yang mengakibatkan Adam dan Hawa tergelincir dari ketaatan yaitu dengan beringkar kepada Allah dan menuruti godaan syaitan. Konseptualisasi dari data 4 membentuk sebuah skema citra eksistensi (eksistence) dengan jenisnya proses (process) antara ranah sumber dan ranah sasaran yang didasarkan pada proses dari sebuah situasi yang baik menjadi situasi yang buruk.

5. Pikeun jalma-jalma anu ragrag sumpah moal rék campur jeung pamajikanana, (Al-Baqarah: 226)

"Untuk orang-orang yang menjatuhkan sumpah tidak akan campur dengan istrinya."

Bagi orang yang meng-ila istri-nya, 
Sumber : Ragrag 'jatuh (untuk barang)'

Sasaran : Sumpah 'sumpah'

Skema Citra : Existence jenis process

Analisis : Pada data (5) termasuk dalam jenis metafora orientasional, yang ditunjukkan dengan penanda linguistik ragrag 'jatuh (untuk barang)' dengan makna leksikal yang dijelaskan dalam KBBI V online adalah terlepas atau meluncur ke bawah secara cepat karena gravitasi bumi. Kata tersebut menggambarkan sebuah benda yang terjatuh dari atas ke bawah secara cepat. Ranah Sumber dari metafora data (4) adalah ragrag 'jatuh (untuk barang)' dan yang menjadi ranah sasaran adalah sumpah. Kata ragrag 'jatuh (untuk barang)' pada kalimat di atas termasuk dalam skema citra eksistensi (existence) yang memiliki ciri proses (process). Skema citra ini menunjukkan adanya proses.

6. Ya Allah Pangéran abdi sadaya! Mugi-mugi Gusti namplokkeun kasabaran nu teu aya kendatna ka abdi sadaya,.. (Al-Baqarah: 250)

"Ya Allah pangeran kita semua! Semoga Allah menumpahkan

kesabaran yang tidak ada putusputusnya kepada kita semua... Jernal Ilmiah Ya Rabb kami, tuangkanlah kesabaran atas diri kami,...

Sumber : Namplokkeun 'menumpahkan'

Sasaran : Kasabaran 'kesabaran'

Skema Citra : Unity jenis Link

Analisis : Pada data (6) termasuk dalam jenis metafora orientasional yang ditunjukkan dengan penanda linguistik namplokkeun 'tumpah atau menumpahkan' dengan makna leksikal yang dijelaskan dalam KBBI
V online adalah tercurahnya benda cair keluar dari tempatnya. Ranah sumber dari metafora data (6) adalah namplokkeun 'tumpah atau menumpahkan' dan yang menjadi ranah sasaran adalah kasabaran 'kesabaran'. Konsep yang ditransfer dari ranah sumber dan ranah sasaran adalah kesabaran sebagai sesuatu hal yang konkret yang dapat ditumpahkan kepada manusia sebagai tempat untuk menanmpungnya. Skema citra yang muncul dari ranah sumber dan ranah sasaran metafora di atas adalah kesatuan (unity) yang memiliki ciri hubungan (link). Skema citra ini menunjukkan adanya hubungan antara ranah sumber dengan ranah sasaran.

\section{Metafora Ontologi}

7. Nya maranéhna anu meuli kasasaran ku pituduh, ku sabab éta maanéhna moal untung dagangna, sarta maranéhna moal meunang pituduh. (Al-Baqarah : 16)

"Ya mereka yang membeli kesesatan dengan petunjuk, maka dari itu mereka tidak akan untung dagangnya, serta mereka tidak mendapat petunjuk."

Mereka itulah orang yang membeli kesesatan dengan petunjuk, maka tidaklah beruntung perniagaannya dan tidaklah mereka mendapatkan petunjuk.

Sumber : Meuli kasasaran 'membeli kesesatan'

Sasaran : Keimanan 'keimanan'

Skema Citra : Unity jenis Link

Analisis : Pada data (7) termasuk dalam jenis metafora ontologi yang ditunjukkan dengan penanda linguistik meuli kasasaran 'membeli kesesatan' yang dalam bahasa Sunda 
mempunyai makna lekasikal membeli kesesatan. Kata membeli membuat seolah-olah kesesatan merupakan benda yang mempunyai wujud atau konkret sehingga dapat dibeli. Ranah sumber dari metafora data (7) adalah meuli kasasaran 'membeli kesesatan' sedangkan yang menjadi ranah sasaran adalah orang kafir dan munafik. Konsep yang ditransfer adalah mereka yang awalnya beriman lalu kembali lagi menjadi kufur dengan menjual petunjuk yang sudah diberikan oleh Allah hanya untuk mendapatkan kesesatan. Kata meuli kasasaran 'membeli kesesatan' termasuk dalam skema kesatuan (unity) yang berciri hubungan (link) karena antara ranah sumber dan ranah sasaran memiliki hubungan dengan metafora lain.

\section{Jeung ari ngajalankeun hukum} qishash téh pikeun kasalametan hirup maranéh, (Al-Baqarah : 179)

"Dan jika menjalankan hukum qishash itu untuk keselamatan hidup kalian"

Dan dalam qisas itu ada kehidupan bagimu,

Sumber : Ngajalankeun hukum 'menjalankan hukum'

Sasaran : Jaminan 'jaminan'

Skema Citra : Unity jenis Link ${ }^{\text {rnal Ilmiah }}$ Analisis : Pada data (8) termasuk dalam jenis metafora ontologi yang ditunjukkan dengan penanda linguistik ngajalankeun yang dalam bahasa Sunda mempunyai makna leksikal menjalankan. Kata ngajalankeun 'menjalankan' membuat seolah-olah hukum qishash itu merupakan sebuah makhluk yang mempunyai kaki untuk berjalan. Ranah sumber dari metafora data (8) adalah ngajalankeun 'menjalankan' sedangkan yang menjadi ranah sasaran adalah jaminan. Hukum qishash yang dimaksud dalam kalimat metafora di atas adalah ketentuan hukuman mati bagi seorang pembunuh, jika seseorang mengetahui bawah nantinya ia akan di hukum mati, tentunya ia akan menahan diri dan hukum tersebut sangatlah penting untuk keberlangsungan hidup. Kata ngajalankeun 'menjalankan' termasuk dalam skema citra kesatuan (unity) yang berciri hubungan (link) karena antara ranah sumber dan ranah sasaran memiliki hubungan dengan metafora lain.

9. Henteu jadi dosa pikeun maranéh lamun maranéh nalak pamajikan anu tacan dicampuran ku maranéh jeung anu tacan ditangtukeun mas kawinna, (Al-Baqarah: 236)

"Tidak jadi dosa bagi kalian jika kalian menalak istri yang belum dicampuri oleh kalian dan yang belum ditentukan mas kawinnya"

Tidak ada kewajiban membayar (mahar) atas kamu, jika kamu menceraikan istri-istrimu sebelum kamu bercampur dengan mereka dan sebelum kamu menentukan maharnya.

Sumber : Dicampuran 'dicampuri'

Sasaran : Pamajikan 'istri'

Skema Citra : Existence jenis process

Analisis : Pada data (9) termasuk dalam jenis metafora ontologi yang ditunjukkan dengan penanda linguistik dicampuran yang dalam bahasa Sunda mempunyai makna leksikal dicampuri. Ranah Sumber dari metafora data (9) adalah dicampuran 'dicampuri' sedangkan yang menjadi ranah sasaran adalah 
pamajikan 'istri'. Kata dicampuran 'dicampuri' pada ungkapan metafora di atas memiliki maksud yaitu seorang laki-laki yang berhubungan dengan istrinya. Dijelaskan bahwa Allah membolehkan laki-laki menceraikan atau berpisah dengan istrinya setelah menikah dan belum berhubungan. Kata dicampuran 'dicampuri' termasuk dalam skema citra skema citra eksistensi (existence) yang memiliki ciri proses (process).

\section{SIMPULAN}

Berdasarkan hasil analisis dan pembahasan ungkapan metafora dalam terjemah Al-Qur'an berbahasa Sunda yang menganalisis jenis ungkapan metafora serta jenis skema citra dari ungkapan metafora tersebut. Ditemukan 15 data ungkapan metafora dalam terjemah Al-Qur'an berbahasa Sunda surat Al-Baqarah yang terbagi menjadi tiga jenis metafora konseptual, yaitu (1) metafora struktural, (2) metafora orientasional, dan (3) metafora ontologi. Dari ketiga jenis metafora yang sudah ditemukan terdapat 5 macam skema citra, yaitu (1) skema citra identitas (identity) sebanyak 1 data, (2) skema citra kekuatan (force) sebanyak 1 data, (3) skema citra wadah (container) sebanyak 1 data, (4) skemaurcitra eksistensi (excistence) sebanyak 3 data dan (5) skema citra kesatuan (unity) sebanyak 3 data. Skema citra yang ditemukan didominasi oleh skema citra kesatuan (unity) dengan jenis link dan eksistensi (excistence) dengan jenis proses (process). Hal itu menunjukkan bahwa terjemahan Al-Qur'an berbahasa Sunda lebih menggambarkan sebuah konsep kesatuan yang saling berhubungan satu dengan lainnya, serta konsep mengenai eksistensi yang didasarkan pada sebuah proses.

\section{DAFTAR PUSTAKA}

Abdullah, M. 2007. Tafsir Ibnu Katsir: jilid 1. Jakarta: Pustaka Imam Syafi'i.

Aulia, Z. N. and Nur, T. 2020. Metafora Konseptual dalam Rubrik UnakAnik Kahirupan Majalah Online Manglé: Analisis Semantik Kognitif. Lokabasa. 11(2). pp. 226236. doi: 10.17509/jlb.v11i2.25251.

Chaer, Abdul. 2007. Linguistik Umum. Jakarta. Rineka Cipta.

Cruse, D. Alan and Croft William. 2004. Cognitive Linguistics. Cambridge: Cambridge University Press.

Danesi, Marcell. 2011. Pesan, Tanda, dan Makna. Yogyakarta: Jalasutra.

Dessiliona, T. and Nur, T. 2018. Metafora Konseptual dalam Lirik Lagu Band Revolverheld Album In Farbe (Conceptual Metaphor in Songs Lyric Revolverheld Band Album in Farbe. Sawerigading. 24(2). p. $177 . \quad$ doi: 10.26499/sawer.v24i2.524.

Devita, A. A. and Nur, T. 2020. Metafora Konseptual dalam Lukas Graham 3. 9(2). pp. 85-92. doi: 10.22460/semantik.v9i2.p85-92.

micjajasudarma, F. 2010. Metode Linguistik. Bandung. Refika Aditama.

Fokkaya, N. 2018. Language Expression as Social Criticism on Iwan Fals' Songs. Gramatika: Jurnal Ilmiah Kebahasaan dan Kesastraan. 3(1). pp. 93-99. doi: https://doi.org/10.31813/gramatika /3.1.2015.124.93--99.

Haula, B. 2020. Metafora Konseptual dalam Judul Berita Kontan.Co.Id: Kajian Linguistik Kognitif. Suar 
Betang. 15(1). pp. 15-24. doi: 10.26499/surbet.v15i1.118.

Irwansyah, Wagiati and Darmayanti, N. 2019. Metafora Konseptual Cinta Dalam Lirik Lagu Taylor Swift: Kajian Semantik Kognitif. Metahumaniora. 9(2). pp. 224231. Available at: http://journal.unpad.ac.id/metahum aniora/article/view/23864/12321.

Karnedi. 2011. Penerjemahan Metafora Konseptual dari Bahasa Inggris ke Bahasa Indonesia Studi Kasus Penerjemahan Buku Teks Bidang Ekonomi. Disertasi. Depok: Universitas Indonesia.

Knowles, Murray and Moon, Rosamund. 2006. Introducing Metaphor. London and New York: Taylor and Francis Group.

Kovesces, Zoltan. 2010. Metaphor A Practical Introduction. New York:
Oxford University Press.

Lakoff, George and Johnson, Mark. 2003. Metaphore We Live By. Chicago: The University of Chicago Press.

Meganova Lyra, H. 2018. Konseptualisasi Sosiokultural Masyarakat Sunda dalam Metafora Konseptual Bagian Tubuh. Metahumaniora. 8(1). p. 58. doi: 10.24198/mh.v8i1.18874.

Riani, R. 2015. Metaphors of Floods, Earthquake, and Volcanic Eruption ( an Anthropological Linguistics Study ). Gramatika: Jurnal Ilmiah Kebahasaan dan Kesastraan. 3(1). pp. 22-32. doi: https://doi.org/10.31813/gramatika /3.1.2015.115.22--32.

Saeed, John I. 2009. Semantics. Oxford: Balckwell Publisher Ltd. 